\title{
Building the New Europe: Western and eastern roads to social partnership
}

\author{
Elena lankova and Lowell Turner
}

It is not the countries that have reduced social spending most or minimized social partnerships that are the leading successes today ... It is therefore not the flexibility of the market, but the existence and adaptability of institutions and regulations which explain success ... The special European way of dealing with change, filtering it through established labour market institutions, leads to positive results. In other words, the baby (institutions) was kept and the water (inefficiencies in the institutions) was at least partially thrown out. This accounts for a large part of European success. Peter Auer (2000, pp. 2-3)

Praised by some, feared by others, neoliberal economic ideas and policies have risen to prominence in Europe over the past two decades. From the extremism of Margaret Thatcher to the more muted conservatism of Helmut Kohl to the current Economic and Monetary Union (EMU), free market ideas have challenged the social market with deregulation and policies of fiscal and monetary austerity. A spectre is haunting Europe: the spectre of Americanisation.

The post-cold war, EMU-oriented 'New Europe' is nonetheless a social Europe, defending, adapting and modernising an essential social dimension within the developing European project. Just as the 1999 'Battle of Seattle' dramatically demonstrated the growing salience even in North America of social dimension debates in an expanding global economy, so does the much more developed European social dimension offer examples of appropriate economic and social policies for integrated markets. Europe can play this forerunner role in today's global economy, we argue, because of longstanding relations of social partnership, in which organised interests, especially business and labour, participate in regularised bargaining processes to craft economic and social policy compromises. Theories of decline-declining unions, corporatism, social democracy, Swedish model, German model, European social model, ad infinitum - notwithstanding, social partnership and the social market economy are alive and well especially in western Europe, adapting and developing in new ways even in eastern Europe, in spite of and alongside the rise of Anglo-American neoliberal economic policy.

While the ways in which neoliberalism and economic integration undermine social partnership and the welfare state have been extensively studied, less attention has been given to the ways in which such economic forces may push actors together, in reinvigorated bargaining relationships, to find workable solutions to difficult problems. In his article, we examine the contemporary status of social partnership in four case study countries-Germany, the United Kingdom, Bulgaria and Poland-as well as for Europe as a whole. In the west, while Germany presents a case of established social partnership under pressure, the United Kingdom has stood over the past two decades on the opposite neoliberal side. In the east, Bulgaria is one 
of the more developed cases of post-communist tripartism, while Poland exemplifies a weaker tripartism that emerged at a later stage of the transformation process. In selecting more and less developed social partnership cases in both west and east, we test the argument that the rise of Thatcher/Reagan/Friedman 'free market economics' is paradoxically driving a resurgence and consolidation of social partnership relations across the new (both western and eastern) Europe.

\section{Social Partnership and the Free Market Challenge}

Social partnership can be defined as regularised bargaining relationships between organised business and labour, often tripartite (with the state playing more or less engaged roles), to set basic wage and employment standards as well as to influence broader economic and social policy. The focus here on social partnership targets an important institutional and procedural component of the social dimension, while avoiding worn-out definitional debates about corporatism. In the consolidation or revitalisation of social partnership, we emphasise two separate indicators: (1) institutions, structures and actors, and (2) policy procedures. While policy outcomes can be significant indicators of social partnership, structures and procedures are the defining characteristics, with a variety of policy outcomes possible. Thus if structures and procedures reflect social partnership arrangements, then this we argue is social partnership, whether policy outcomes are Keynesian, 'supply-side Keynesian' (Falkner, 1999), austerity-oriented, monetarist, or some hybrid in between or beyond.

The contemporary spread of freer markets, especially when guided by market fundamentalist ideology, does threaten to overwhelm and undermine social standards of all kinds. Yet if we look across Europe today, especially western Europe, side-by-side with deregulation, fiscal and monetary austerity, and high unemployment, we still see, certainly in international and comparative perspective, widespread prosperity, relative equality, substantial welfare states, strong labour unions, and extensive social and workplace standards. The danger, of course, is when governments go over to neoliberalism and unions are weak. It is reasonable, as many analysts do, to see national governments and the European Union as neoliberal advocates of EMU, and to emphasise a variety of indicators for national union decline and the failure of unions to move decisively to the European level. Yet this is only part of the story. Unions also remain strong in many European countries. In several cases, they find themselves in the midst of ongoing processes of modernisation and revitalisation, and from Germany to Ireland to Italy strongly organised unions participated in the 1990s in significant tripartite bargaining at national and sectoral levels, for new 'social pacts' and other policy compromises (Auer, 2000; Visser, 1999).

In the east, the coming of markets has been closely linked to the dismantling of encompassing communist economic organisation and social policy. While new or reformed unions have reeled under the onslaught and in most eastern countries remain weak, important tripartite processes have nonetheless helped shape the coming of markets in eastern Europe (lankova, 1998; 2002). Policy-makers in CEE had to introduce transformative policies in the early 1990s in the midst of a deep international recession, stagnant international trade, constrained capital markets, a deepening debt crisis, and hard conditions for loans and 
assistance. A strong domestic effort to preserve social peace and legitimate the actors in a period of regime change and economic restructuring underpinned the emergence and maintenance of tripartite transformative negotiations in the post-communist region.

The ILO, World Bank, IMF, and European Union have also contributed to the development of tripartism. The ILO has packaged its philosophy of tripartism with practical expert assistance. While international lending institutions favoured neoliberal policies (fiscal and monetary austerity, anti-inflation policies, shock therapy) for states extricating themselves from state socialism, they have also supported the establishment of social dialogue among governments, unions, and employers. Negotiations have been broadened to include labour and employer federations, and IMF and World Bank missions have required the conclusion of national social peace agreements as a condition for granting loans. In Hungary, the World Bank's Human Resources Development Program promoted the establishment of regional retraining centres run by a national tripartite body, the National Training Council (Hethy, 1994: 316). In Bulgaria the 1992 revival of tripartism was closely linked to negotiations with the IMF (Thirkell and Tseneva, 1992). The EU's increasing importance as a regional power, its PHARE Social Dialogue Project as well as eastward enlargement processes have all reinforced tripartite arrangements in the region.

\section{Seeking Social Europe}

'Social Europe' - a theoretically vague term but also a much debated political concepthas at its heart a collective societal effort to limit social inequality through government intervention, with an active role played by organised 'social partners' representing labour and business. Social Europe envisages economic success building on deep social foundations, on a shared belief that the fruits of capitalist enterprise should be distributed across society in policies of social and economic security. First and foremost a concept of comparative capitalism, social Europe contrasts sharply with the US model of capitalism featuring individualism, minimal state involvement in the economy, and adversarial relations between labour and business rather than dialogue and concertation (Albert, 1993). Despite the wide variation among European countries in terms of social policies, the gap separating them in particular from the United States is much wider and more significant (Wilensky, 2002).

It is commonplace to seek social Europe in the wrong places. People look at the EU level and find that not enough is there. While Europe is integrating economically, neither democratic corporatist arrangements, strong social policy (comparable to the welfare state) nor unified European trade unionism appear possible at the European level. At the same time, European economic integration is undermining the power of national governments in a variety of areas including social policy, while undercutting national union bargaining strength (Streeck, 1991). Social Europe, it has seemed to many, is dead on arrival.

The most important locus of social Europe, however, remains at the national level. While facilitating neoliberal policy reforms such as budget restraint and business tax reform, social partnership bargains also set the terms of implementation, defend national health systems, pensions and unemployment benefits, promote education and vocational training, and 
provide institutional anchors for labour unions and collective bargaining. Governments and social partners also expand social policy by implementing directives from the EU- on health and safety at the workplace, environmental regulations, new protections for 'posted workers,' limitations on working hours, new rules on gender equality in the workplace, the establishment of European works councils and much more. EMU and other neoliberal economic pressures have arguably driven a 'renaissance of national corporatism' (Grote and Schmitter, 1999).

EU-level social policy can be viewed as a significant supplement to national policy. The directives mentioned above are all examples of new social regulations developed with the active participation of European labour and business as well as national governments. Under pressures of economic crisis and growing international competition in the 1970s and 1980s, the European social space began to expand as a necessary complement to the internal market. In 1988 the Commission added an explicit social dimension to the single market initiative. The strongest motivation was a mounting fear of social dumping, a potential result of increased regional disparities, as investment and jobs moved (it was feared) from the higher-wage north to the lower-cost south.

The Single European Act (1987) set the goal of creating the internal market by 1992, and committed member states to harmonise workplace health and safety measures at the highest possible level. SEA gave the Commission responsibility for promoting dialogue between the social partners, to reach common positions on workplace issues, especially for the development of European-level collective bargaining. The Act also emphasised the need for economic and social cohesion to reduce regional disparities. The 1988 White Paper entitled 'Social Dimension of the Internal Market' had unemployment as its main target and proposed a series of policy measures (Springer, 1992).

In 1989, after considerable debate, 11 of the 12 member nations adopted a Community Charter of Fundamental Social Rights. While this 'Social Charter' was adopted as a declaration, without the force of law, a path-breaking linkage was established for the Community between social policy and human rights. The Treaty on European Union (the 'Maastricht Treaty' ratified in 1993) essentially adopted the Social Charter as the 14th Protocol to the Treaty (the 'Social Protocol'), including an agreement on social policy. The Treaty restated the objectives of social policy - the promotion of employment, improved living and working conditions, proper social protection, dialogue between management and labour, and the development of human resources with a view to achieving durable high employment and combating discrimination. The Amsterdam Treaty of 1997 incorporated the Social Protocol into the body of the Treaty. Although the role of European institutions and legislation in the field of social policy remains limited (Archer and Butler, 1996; Tsoukalis, 1997), significant first steps have been taken, with more sure to follow as the new EU Constitution comes into play and the European Parliament and other institutions are strengthened.

Social dialogue at the European level, in spite of the limitations, has scored some real achievements. New EU directives have forced changes in national laws that strengthened social policy (from working hours in the UK to gender equality in Germany). Millions of EU citizens are benefiting from expanded parental leave and improved rights for part-time workers as a result 
of agreements negotiated between the Union of Industrial and Employers' Confederations in Europe (UNICE) and the ETUC. As integration proceeds, the emergence of a 'corporatist policy community' becomes increasingly plausible (Falkner, 1998), not one that displaces national level social partnerships but one that complements them.

For the east, social Europe is an important catalyst for the harmonisation of domestic legislation with European common law, the acquis communautaire, in the area of national social dialogue. Accession institutions (association councils, association committees, and joint parliamentary committees) have developed as joint bodies between the EU and each applicant country. Trans-European networks involving the EU's political parties and other social groups, with their respective counterparts in the applicant countries, are another means for integrating the post-communist countries into Europe's socio-political structures.

The European Trade Union Confederation (ETUC) and the Economic and Social Committee (ECOSOC) of the EU, for example, have organised meetings and hearings in Brussels, Warsaw, Tallinn and elsewhere to enable applicant countries' social and economic organisations to voice their opinions. With support from the European Commission, ECOSOC organised a major conference in 1999 that brought together 93 social partner representatives from the EU with 80 from the applicant countries to discuss the role of social partners in enlargement and accession processes, emphasising the development of social dialogue structures and activities in the applicant countries.

Trade unions from western Europe, united in the ETUC, have developed a policy of active cooperation with ETUC member unions in the CEE applicant countries. With support from an ETUC standing committee on integration, western unions have helped their counterparts in the applicant countries set up standing committees on European integration, with specialised working groups to influence their own governments with union views on accession.

ECOSOC has also forged and consolidated bilateral links with groups from the applicant countries, in joint consultative committees on economic and social issues. Such committeesfirst created in Hungary (1997) and Bulgaria (1999) - included representatives of ECOSOC as well as economic and social interest groups in CEE applicants. Committee members represent employers, unions, farmers, consumers, and women, and have paved the way for enlargement by promoting domestic dialogue as well as cooperation between economic and social interest groups in the EU and CEE.

\section{Western Europe: Social Partnership and Welfare State Reform}

Writing about labour market successes of the 1990s in Austria, Denmark, Ireland and the Netherlands, Peter Auer (2000) makes a persuasive case based on extensive comparative research: social partnerships in western Europe, their institutions and processes, have promoted successful economic reform and defended labour market and social policy. If western European nations have had to make concessions to neoliberal economic policy in present 
European and global markets, they have done so in ways that mitigate negative effects while reconsolidating relations of social partnership and the inclusion of organised labour.

Jelle Visser makes a similar but broader argument that includes Auer's four countries as well as Italy, Portugal, Spain, Finland - and in a more germinal way Germany and Belgium. He argues: 'One of the interesting phenomena of recent years is the resurgence of a national social dialogue between labor unions, employers' associations and governments in many European countries' (Visser, 1999, p. 4). In this analysis, a new generation of social pacts is driven by the need to meet EMU convergence criteria, and made possible by past learning on the part of governments, employers and unions concerning the dangers of unilateral action and the positive gains to be made through social dialogue.

Along with the flowering of social pacts comes a flowering of the literature, itself indicative of a growing awareness on the part of academics and policy makers of the continuing salience of social partnership. Recent books and articles on western Europe have titles such as: 'The Renaissance of National Corporatism' (Grote and Schmitter, 1999), 'EU Social Policy in the 1990s: Towards a Corporatist Policy Community' (Falkner, 1998), 'The Resurgence of Italian Unions?' (Locke and Baccaro, 1999), 'Fighting for Partnership' (Turner, 1998), 'Employment Revival in Europe' (Auer, 2000), and 'The Revival of Social Dialogue in Europe' (Visser, 1999).

Neoliberal economic policy in its purest forms promotes deregulation and the dismantling of institutions, clearing away barriers to free market outcomes such as strong unions, collective bargaining and government regulation. While policies of fiscal and monetary restraint were widely implemented in the run-up to EMU, with painful effects such as high unemployment, such policies were often agreed upon and implemented in processes of social dialogue. Negative effects were mitigated through collective bargaining as well as the policies of still extensive welfare states (including national health care, universal education and training and substantial unemployment insurance).

Institutions and procedures of social partnership thus remain central to the political economies of most west European countries. At the same time, policy outcomes, driven in neoliberal directions by European and global markets, nonetheless continue to incorporate strong labour and social standards. Free market economics, in other words, far from dismantling social partnership in western Europe, is paradoxically driving (and has been tempered by) social pacts, dialogue and partnership negotiations.

While the social dimension at the European level is by no means insignificant, the consolidation of social partnership in this neoliberal era has occurred most prominently at the national level. Above we have mentioned a range of countries studied by Auer and Visser. Here, as additional evidence, we present the cases of two large western European countries, Germany and the United Kingdom, the first a leader in postwar social partnership relations, the latter a laggard even before the Thatcher onslaught. 


\section{Germany: modernizing the social market}

With all the agonising over unification and subsequent economic problems and current debates on economic policy reform, German employer associations and unions continue to play instrumental roles not only in comprehensive collective bargaining but in a wide variety of policy reform discussions, formal and informal. For every concession to fiscal austerity and EMU convergence criteria, there are also demonstrations of the continuing prominence of social partnership in regulating the changes. And in any case strict monetary policy has always been a feature of the German Federal Republic.

German employer associations and unions, although neither are as comprehensive as they once were, remain deeply engaged in policy debates and negotiations as well as collective bargaining. Although tempted by the 'siren song of deregulation' (Allen, 1998) and weakened by defections, German employers as a whole cannot bring themselves either to attack or to withdraw from their close social partnership relations with the unions (Thelen, 2000). While German unions have lost membership density over the past decade (now under 30 per cent), they remain powerful in the capacity to set wage standards for the entire economy as well as to mobilise the workforce in widespread job actions when necessary (Thelen, 2001; Turner, 1998).

German unification, formalised in 1990 but still an ongoing process, presented a massive challenge to the social market economy. While the financing necessary to make unification work (transfers averaging \$100 billion/year from west to east throughout the 1990s) has limited other welfare state expenditures and raised taxes, policy compromises have often emerged in tripartite negotiation. The recently renewed Solidarity Pact of 1993, for example, a set of economic and social policies for eastern Germany, was agreed in negotiations including federal and state governments, employer associations and unions (Sally and Webber, 1994).

Policy outcomes have been mixed. Unemployment remains high and chronic, especially in eastern Germany. Yet wages remain high, prosperity is widespread, and no one talks seriously of cutting back comprehensive welfare state policies such as health care, education and vocational training. Bargaining among social partners continues to influence policy direction, incorporating neoliberal elements viewed as necessary by policy makers while defending and modernising key elements of the welfare state and social market economy.

The biggest problem for a strong German social model, at the core of a developing social Europe, may be the long-term viability of cohesive interest groups. Kathleen Thelen has effectively shown why German employers on the whole stay together and remain committed to social partnership (Thelen, 2000; Thelen and Kume, 1999). Others have shown the continuing strength of German unions, even in the face of extraordinary challenges (e.g., Turner, 1998). We believe that the latter is decisive in the German case (and that an excess of firm-centrism is an important flaw in an otherwise insightful 'varieties of capitalism' literature; Hall and Soskice, 2001). Simply put, in Germany as in other countries, weak unions encourage employers to defect while strong unions push employers together for mutual support. The problem is that German unions face new challenges, potentially serious, which they have not yet faced in a full way. 
Even with strong institutions and the proven capacity to strike with solidarity and enthusiasm, union membership levels are on the decline. While unions have remained influential in German society thanks to entrenched institutional position backed by mobilisation capacity, declining numbers over time can only mean declining influence. Institutional position can be defended only so long in circumstances of continuing organisational erosion.

The problem now is that while unions remain powerful in their strongholds, they are weak in their capacity to organise growing groups in the workforce such as women, the young, and white-collar workers. Yet German unions still do not have well developed, widely accepted strategies to organise the unorganised. They recognise the problem, discuss it widely, write articles and position papers, hold conferences. On a broad scale, however, they have not yet moved beyond rather traditional approaches: exhorting shop stewards and works councillors to sign up the non-members in their workplaces; offering incentives to members to sign up colleagues; and exploiting situations of conflict (in collective bargaining or other job actions) to bring in new members. None of these time-tested strategies, however, appear adequate to the current challenges: to push toward major breakthroughs in organising new groups of workers such as women and youth.

German unions are strong because of their institutional position in the social market economy and because they have continually renewed the commitment of members and works councillors in rank-and-file mobilisations (including warning strikes). As a result, German unions are so solidly positioned within the political economy that the urgent need for new organising strategies may go unmet. Against the potential turbulence that a shift toward fuller rank-andfile mobilisation may bring, the institutional conservatism of the still powerful prevails.

We do not however join the doomsayers regarding the future of German unions. Institutional anchors and the capacity for viable collective bargaining compromise remain impressive. If and when German union leaders decide to organise the unorganised and to negotiate substantial economic policy reform, they have impressive resources at their disposal. There is no reason to think that at some point they will not do this, under rising economic and political pressure including membership demands.

In the meantime, the German social market economy remains a strong base from which to continue building a social Europe. Social partnership here reinforces the possibilities for social partnership elsewhere-just as developing weaknesses here are problematic for Europe as a whole.

\section{United Kingdom: from neoliberal stronghold to soft social partnership?}

If Germany is the large European country with the strongest social partnership tradition, the United Kingdom is clearly the weakest case. For most western European countries, it is the pressures of EMU plus the previous existence of social dialogue among social partners that together have made the reconsolidation of social partnership bargaining a likely outcome (Visser, 1999). In the UK, by contrast, the absence of such institutions and practices has meant that other factors have combined with neoliberal economic pressures to produce a new 
(although still limited) interest in European-style social partnership. These factors include the following.

First, disillusionment throughout the 1990s with (and arguably the barrenness of) Thatcher/Major economic and social policies generated a widespread desire to move beyond market solutions alone. This is the perspective that Tony Blair and the Labour Party rode successfully to landslide election victories in 1997 and 2001. Second, the Blair government itself has actively promoted a limited version of social partnership, seeking to bring traditionally adversarial labour and management together around policies of economic growth, labour market flexibility and union moderation.

Third, European influence has had an important effect. While Margaret Thatcher derided social partnership as old fashioned continental socialism, Tony Blair has moved the UK closer to Europe, fulfilling a campaign promise by eliminating Britain's opt-out on the Maastricht Social Protocol. The Blair government has openly praised European-style social partnerships, while large British employers have negotiated new European works councils and sought better relations with their unions. And the European influence has pushed some British unions toward an acceptance of social partnership, at firm, industry and national levels.

Fourth, therefore, British unions, traditionally adversarial and committed to voluntarism, reassessed their strategic orientation in the wake of serious decline at the hands of Margaret Thatcher and her anti-union policies (dropping from 54 to 30 per cent union membership density from 1979 to 1997). 'New Unionism,' promoted by the TUC, advocates social partner relations with employers while at the same time stepping up active recruitment and organising efforts. The Labour government's Employment Relations Act of 1999 promotes both partnership and representation in ways that support union efforts (Heery et al., 2001).

Unlike Germany, the UK has neither an institutional base for social partnership nor established bargaining procedures for policy making. Barriers to reform include not only a tradition of voluntarist ideology and practice, but highly decentralised business and labour organisation. On the business side, interest in social partnership is by and large limited to the firm level, with general opposition to broader industry or national level initiatives. British labour remains decentralised in its bargaining and coverage efforts. At the same time, several unions have merged over the past decade into 'super unions,' seeking to combine the strengths of traditional decentralization with stronger central capacities. The new super unions, combined with the apparent recent reversal of union decline in the UK, could conceivably lay the institutional groundwork for a developing British version of social partnership (Heery et al., 1998). The election in 2003 of more militant leadership at two of the largest unions (TGWU and $\mathrm{GMB}$ ) may paradoxically reinforce this prospect, if the unions are strengthened while employers and Labour government are shaken up by the new militance.

As in the German case, we believe that the decisive actor here may well be organised labour (again in opposition to a rather stifling de-emphasis on labor as an independent actor in the 'varieties' literature). If unions can use their own internal reforms as well as new legislation to stabilize or even push union membership levels upward, a stronger foundation can be built 
for British social partners to meet as equals in expanded bargaining. If the unions can do this, even in a context of rising industrial conflict and anti-privatisation mobilisation - or because of these - the push for European-style inclusion at firm, industry and even national levels (much of it informal and behind the scenes) can be expected to persist.

Critical to this process is the unresolved tension between social partnership, organising and militance inside the labour movement. A radical break with British labour's adversarial past, the social partnership approach seeks to rebuild unions through good relationships with business leaders via win-win bargaining and a new understanding of the realities of competition in the global economy. The social partnership approach aims at nothing less than to (1) bring Britain more fully into the European Union, (2) raise both productivity and wages while giving employers less cause to oppose union recognition, and (3) improve the British economy while strengthening the unions.

It is unlikely, however, that social partnership efforts along with new legislation will be enough to revitalise the British labour movement. For partnership to work from a labour point of view, unions must be strong, capable if necessary of widespread rank-and-file mobilisation (as the German case demonstrates). And for the new legislationto mean anything, unions must use it actively to organise the unorganised. A central element of the TUC's New Unionism is a commitment to organise new members, for 'in-fill' as well as in new organising, directed at nonunion workplaces in service industries, electronics and other places where union presence is weak (Heery et al., 1998).

The commitment to organising as well as renewed militance point toward a strengthened rank-and-file unionism. That the advocates of social partnership, organising and militance are often quite opposed in ideological and practical orientations (expressed at times in vociferous debate) does nothing to diminish the fact that for the revitalisation of the British labour movement they may well be necessary complements. The prospects for a British-style social partnership depend very much on future union strategy and the surprising but now very real possibility of renewed union strength.

\section{Eastern Europe: The Coming of Markets and Social Partnership}

Most of the formerly communist countries, very early in their transitions, approached the coming of markets in part by reviving collective bargaining and using tripartite forums for social dialogue among the state, trade unions, and emerging employers at both national and subnational levels (lankova, 1998, 2000). Tripartism was to balance the dynamic conflicts between the public interest in transforming the old social order and a variety of group and individual interests in keeping wages and living standards at acceptable levels. By legitimating the new 'social partners' and giving them voice in the direction of change and distribution of the burdens of transformation, tripartite forums helped to prevent eruptions of industrial and social discontent in the difficult early years of economic reform, thereby facilitating the building of a new capitalist order with a minimum of social unrest. 
Post-communist tripartism was most manifest in two major areas. Given its wide acceptance as a means to distribute the social burden of restructuring across the population, tripartism played a prominent role in deciding distributional issues such as wages, incomes, and social and employment policies. And tripartism also played an important role in democratisation, since the deepening of political democracy depends on access to the policymaking process by groups representing the interests of different sections of society.

Here we present evidence of emerging social partnership structures and procedures in the post-communist region, focusing on two countries in particular-Bulgaria and Poland. While each developed tripartite institutions in the aftermath of the 1989 breakthrough, the contrasting legacies of their extrication paths, along with differing levels of social partner commitment to social dialogue, account for notable variation in the timing, organisational structure and bargaining patterns of tripartism.

\section{Bulgaria: post-communist restructuring and tripartism}

After the collapse of the Zhivkov regime in November 1989, the clandestine trade union Podkrepa, formed in February 1989, emerged into the open while existing unions experienced a steady decrease in membership. To gain political legitimacy and to prove itself capable of defending member interests in the transition to a market economy, the old unionsreconstituted as the Confederation of Independent Trade Unions in Bulgaria (CITUB)-initiated negotiations and regular consultations with the Lukanov government. For its part, the government sought public negotiations with the unions political legitimacy in the face of consolidating democratic opposition. Podkrepa joined the bargaining forum in April 1990, moving from a primarily political stance toward a more traditional union orientation for the defense of member economic interests.

Social dialogue facilitated the emergence and legitimation of more distinct employer organisations, as employers came under pressure from other actors, especially trade unions. Thus the National Union of Economic Managers (NUEM) was formed in January 1990 with the assistance of the CITUB (Petkov and Gradev, 1995). The Bulgarian Industrial Association (BIA) and Chamber of Commerce, as well as two more employer organisations-the Union of Private Economic Enterprises and the Vazrazhdane Union of Private Entrepreneurs (both founded in December 1989)-became partners in the social dialogue.

The most important accomplishments of the emerging national tripartism included: the Law on the Settlement of Collective Labor Disputes (adopted by the Grand National Assembly in March 1990); the signing of a general agreement on urgent social and economic problems, between the government, CITUB and NUEM (March 1990); and the adoption by the social partners of General Guidelines for the Conclusion of Collective Contracts and Agreements During 1990 (April 1990). The creation on April 5, 1990, of a National Commission for Coordination of Interests marked the institutionalisation of social dialogue in Bulgaria.

Social partnership relations were suspended in late 1991 by the newly formed neoliberal government of the Union of Democratic Forces. Following strong pressure from unions and international organisations, however, this government established a new social dialogue body, 
the National Council for Social Partnership, in May 1992. Finally in early 1993, the National Council for Tripartite Cooperation was formed following adoption of a new Labor Code that made social dialogue mandatory.

The National Council continues its work to the present day, focusing much of its attention on wages. The social partners have to agree on the national minimum wage and other protected payments - such as monthly additional child allowances and unemployment benefits-which are calculated as a percentage of the minimum wage. The social partners also negotiate wage increases and protection against inflation for both the public sector and for state enterprises in manufacturing. Strategies and policies in the area of employment and unemployment are also regularly discussed by the Tripartite Council, and important laws and normative documents eventually issued by the government often have been prepared by the Council. The goals, principles, criteria and mechanisms of incomes policy have also been major areas of discussions within the tripartite forum. Discussions have included the formation, regulation and indexation of wages in manufacturing and the public sector, indexation of pensions, unemployment payments, minimum wage, social aid and child allowances. Most aspects of the economic reforms were also discussed in the Council. These included price controls on selected basic goods; legislation concerning the financing of small and medium enterprise development; privatisation and industrial restructuring; and health insurance.

As the economy deteriorated sharply in 1996 as a result of mismanagement by the Socialist Videnov government, social dialogue within the National Council was discontinued. Massive protest actions and strikes across the country in December 1996 and January 1997 led to the resignation of the government and to early parliamenttary elections in April 1997. With the formation of the Kostov cabinet (Union of Democratic Forces) in May 1997, social dialogue was quickly restored. The introduction of a currency board in July at the insistence of the IMF stabilized the Bulgarian currency, but challenged the government and the social partners to work closely with the international financial institutions which in effect became part of the revised social dialogue system. Under the terms of a Charter for Social Cooperation and Memorandum for Priority Common Action (signed in October 1997 between the prime minister and the social partners), the unions agreed to support the Currency Board on the understanding that social dialogue would deepen. The Charter for Social Cooperation aimed to mobilise a broad social consensus for ongoing economic and social reforms and to promote democratisation. The goal was to bring social dialogue to 'European standards,' especially after Bulgaria became an official candidate for EU membership in 1996 and had to harmonize and comply with the acquis communautaire as a precondition for entry. As part of the accession effort, Bulgaria is expected by the EU to develop and maintain autonomous social dialogue among the social partners.

In 1998-99 a series of laws brought Bulgarian legislation in the social sphere largely in line with European laws, and created seven other tripartite organs to complement the activities of the National Council for Tripartite Cooperation and deal with social insurance, employment, vocational training, social assistance, work conditions, and the rehabilitation and social integration of disabled people. Five specialised social funds, each governed with the broad 
participation of the social partners, were established for social security, vocational training and unemployment, working conditions, social assistance, and rehabilitation and social integration.

With progress in social, economic and political restructuring in the 1990s the importance of tripartism gradually decreased. Anticipated EU accession, however, has given new impetus to the maintenance of social dialogue in Bulgaria-including the estasblishment of a new tripartite Economic and Social Council in accordance with general European practices and standards and more specific EU accession requirements.

\section{Poland: from ethical truce to institutionalized tripartism}

Poland was the first country in the Soviet bloc to break from communist rule, and it did so in processes of negotiation and compromise. Yet after the collapse of the regime, Poland, unlike any other country in the region, did not develop institutionalised 'social peace' tripartism for several years, until early 1994. The reason lies not so much in Poland's deep embrace of neoliberal reform and interest-based politics. The popularity of neoliberal ideas was present not only in Poland but all over the region, as a natural move towards the market. What made the Polish tripartite scenario especially problematic was the complex interweaving of neoliberal and interest-based politics with the unique ethics-based politics found in Poland.

In the post-1989 era, Poland's political system was dominated by the Solidarity movement, not by parties (Millard, 1994). With its commitment to spontaneity and informality, Poland's ethical civil society (Linz and Stepan, 1996) prevented Poland from embracing in 198991 a formal tripartite arrangement for the introduction of neoliberal economic reforms. Poland did not need to develop specialised tripartite arrangements to guarantee social peace. The high political and moral consensus developed prior to the election of 1989 could be radically and successfully mobilised to produce broad approval for the implementation of the 'shock therapy' plan of Finance Minister Balcerowicz beginning in January 1990.

Reflecting the ethical bonds of Poland's civil society, informal social partnership arrangements found expression in Poland's parliament, and in bargaining between the government, labour unions (especially Solidarity), and emerging employers (notably the Confederation of Polish Employers, KPP). To combat the most acute problem of economic reform, namely unemployment, a national system of tripartite employment councils was established early in the 1990s. However, despite Solidarity's efforts to lobby directly in parliament and in informal talks with the government for social mechanisms to counterbalance neoliberal reforms, the considerable losses in real income quickly undermined the sociopolitical consensus for radical change and provoked substantial unrest among the population. The strike wave in the summer of 1992 marked an important step in the erosion of consensus at the top of the Polish polity. A more formal and inclusive mechanism was needed to limit mass discontent and guarantee continuation of economic reforms.

The Suchocka government and, in particular, the Minister of Labor, Jacek Kuron, proposed negotiations to develop a social pact-the Enterprise Pact. The government's main intention was to grant effective guarantees of minimum security in return for the continuation of reforms and privatisation. The Pact on State Enterprises in Transformation was signed on 22 
February 1993, in three versions: with Solidarity, with the All-Poland Trade Union Alliance (OPZZ), and with seven branch unions. In return for union acceptance of the privatisation of state-owned enterprises, workers were granted important concessions: they would help determine their enterprise's privatisation strategy, they would receive 10 per cent of their enterprise's stock, and union representatives would sit on the boards of newly privatised companies.

The government expected the 1991 Trade Union Act and the collective bargaining aspects of the Enterprise Pact to discourage labour disputes, but the austerity of economic reforms and the absence of a stable process for resolving disputes increased tensions on the shopfloor in 1993, and many strikes occurred before the Enterprise Pact legislation could be passed. The dissolution of Parliament in 1993, almost immediately after the successful negotiation of the Pact, was clear evidence of the fragile balance of Poland's tripartite compromise.

The functions of the Tripartite Commission on Socio-Economic Issues envisaged in the Enterprise Pact were laid out in a government decree in February 1994. The signatories of the Enterprise Pact automatically became members of the Commission. The Commission was established to monitor economic processes and basic macroeconomic relations and to formulate social and economic policy proposals. The latter included public sector employment policy; social benefits; and the relation between consumption and investment.

The most noteworthy function of the Tripartite Commission is to set target maxima for wage increases in public and private sector enterprises employing over 50 persons. The Law of 16 December 1994 on the establishment of a new national collective bargaining system abolished the popiwek, a punitive tax of up to 100 per cent on all wage increases above wage norms, linked to a government 'inflation coefficient' set for certain state firms. The new system, in effect since 1995, represented 'a turning point in the relations between government, employers and unions' (Kabaj, 1998: 241). In July of each year, the government provides the Commission with projected macroeconomic indicators for the following year on real GDP growth, inflation, and the proposed maximum annual increase in average monthly wages. By 31 August, the Commission is required to determine the maximum annual increase in average monthly wages and approximate indicators for each quarter relative to the same period of the previous year. The target maxima set by the Tripartite Commission have an important influence in enterprise bargaining over wage increases, alongside the financial situation of the firm (Kabaj, 1998: 241).

General elections in 1997 returned to government the post-Solidarity parties, grouped under the AWS umbrella. While the right-wing coalition government of Jerzy Buzek proved determinedly neoliberal, accelerated EU accession processes along with Poland's eagerness to become a member of the EU soon pushed this reluctant government towards maintaining an established social dialogue that incorporated increasingly autonomous social partners, as preconditions for EU membership. 
To conclude, the specific Polish variant of post-communist tripartism rested on close contacts between Solidarity unions and governments. Guided by the ethos and historical symbolism of the broad Solidarity movement, Poland had less need than its neighbours to develop 'social peace' cooperation and tripartism for legitimation purposes with the coming of neoliberal reform. With deteriorating living standards, however, the crystallisation of more distinct economic interests was institutionalized in tripartite conciliation by 1994 . With anticipated EU accession, Poland like Bulgaria is committed to maintaining and developing tripartite structures at the heart of its socio-political system.

\section{Conclusions}

In its struggle for new identity following the collapse of state socialism in 1989, in a context of rapidly expanding global markets, the New Europe, in different ways both east and west, has turned to institutions of social partnership for regulation and legitimacy. The challenge has been to make social partnership flexible enough for the unpredictable demands of open markets.

In the west, the process has been straightforward if somewhat surprising, especially for the many theorists of union and corporatist decline. Starting in the early 1990s, a resurgence of social partnership negotiations across western Europe has in fact been driven to a large extent by neoliberal economic policies initiated at the European level. The deepening of European integration with the creation of EMU has provided new incentives for negotiated solutions, from Denmark and Ireland to Spain and Italy, and even in a partnership laggard like the United Kingdom.

In the east, the neoliberal return to the market and in particular the establishment of labour markets and the need to preserve social peace in times of uncertainty have pushed postcommunist governments from all-encompassing economic regulation towards policies aimed at creating viable collective bargaining institutions, initially for the most part tripartite in character with continuing state involvement in the economy. The international lending community, despite its distinct neoliberal identity, has also advised CEE governments to maintain social dialogue with interest groups as a condition for loans and the preservation of social peace. This short-term, transformationdriven generator of tripartism across the region was consolidated on a more permanent basis in the EU accession process. The launch of the EU's 'Social Dialogue' project in the early 1990s aimed at promoting the organisational capacities of CEE's social partners. The articulation in 1998 of an EU accession norm on social dialogue played an important role in maintaining tripartism and defending it against potential attacks by neoliberal governments. Tripartite institutions and arrangements, which in many countries declined in importance as the transformation advanced, thus gained new support as preconditions for EU entry in ongoing accession processes.

This general trend in post-communist social partnership reflects the increasing importance of the European level in promoting social dialogue across today's Europe. In countries where social actors have been generally less committed to partnership negotiation, such as the United Kingdom and Poland, European level policies and institutions have been 
important catalysts in promoting social partnership. In the United Kingdom, emerging social partnership strategies have aimed in part at bringing Britain more fully into the European Union. In the CEE region, especially in countries with greater commitments to neoliberalism and free markets such as Poland, public debates on accession have raised concerns about the European social model and its social-democratic policies. Yet even Balcerowicz, the prominent Polish architect of 1990-91 shock therapy reforms, while raising concerns about the EU's imposition of social standards in its eastward expansion, has acknowledged that such standards must be accepted for CEE applicants to become EU members (Balczerowicz, 1999).

A common problem in the literature is that analysts fall into either/or, zero-sum perspectives. Politics against markets, markets versus social democracy, globalization or European integration versus the power of the nation-state, realism versus functionalism, centralisation versus decentralisation, wage moderation versus union strength, tripartism versus neoliberalism-all of these, we believe, are examples of ways in which polarised debates undermine clarity of analysis. Just as it is much easier to identify problems than it is to offer viable solutions, so is it easier to analyse crisis than to explain success. Brilliant academics have told us why the Wall would never come down, why American and European economies could not compete with the Japanese, why European integration was the beginning of the end for union influence. All of these predictions, and the analyses upon which they were based, have proven overstated if not flatly wrong.

Chronic pessimists have also told us that the European social dimension is but window dressing for a neoliberal project. Yet social and labour activists involved in other processes of regional integration from Mercosur to NAFTA and beyond look first and foremost to the European Union for a model of how social and labour standards can be developed along with expanded regional and international trade. While neoliberal economic policies may predominate today in Europe as across the global economy, the consolidation of social partnership structures and procedures inside western and eastern European countries-and to a less developed but growing extent at the EU-level as well-lays a continuing groundwork for interest group inclusion and future policy reform. 


\section{References}

Adam, J. (1999), Social Costs of Transformation to a Market Economy in Post-Socialist Countries: The Cases of Poland, the Czech Republic and Hungary (New York, St. Martin's Press).

Albert, M. (1993), Capitalism Vs. Capitalism (New York, Four Walls Eight Windows).

Allen, C. (1998), 'Institutions Challenged: German Unification, Policy Errors, and the "Siren Song" of Deregulation,' in L. Turner (ed.), Negotiating the New Germany: Can Social Partnership Survive (Ithaca, NY, Cornell University Press), pp. 139-158.

Archer, C. and F. Butler (1996), The European Union. Structure and Process (New York, St. Martin's Press).

Auer, P. (2000), The Employment Revival in Europe (Geneva, ILO).

Balcerowicz, L. (1999), 'Europe Growing Together,' in V. C. Price, A. Landau and R. G. Whitman (eds), The Enlargement of the European Union: Issues and Strategies (London and New York, Routledge), pp. 3-9.

Deppe, R. and M. Tatur (1994), 'Trade Unions in the Transformation Process: Comparative Observation on the Role of Trade-Union Representation in Poland, Hungary, Russia, and in the Territory of the Former GDR', International Journal of Political Economy, 24, 2, 7-38.

Ekiert, G. and J. Kubik (1997), 'Collective Protest and Democratic Consolidation in Poland, 1989-93,' Pew Papers on Central Eastern European Reform and Regionalism, No. 3 (Princeton, NJ, Center for International Studies, Princeton University).

Ekiert, G. and J. Kubik (1999), Rebellious Civil Society: Popular Protest and Democratic Consolidation in Poland, 1989-1993 (Ann Arbor, University of Michigan Press).

Falkner, G. (1998), Social Europe in the 1990s: Towards a Corporatist Policy Community? (London, Routledge).

Falkner, G. (1999), 'Corporatist Governance and Europeanisation: No Future in the MultiLevel Game?' Current Politics and Economics of Europe, 8, 4, 387-412.

Grote, J. and P. Schmitter (1999), 'The Renaissance of National Corporatism,' Transfer 1-2/99, 34-63.

Hall, P. and D. Soskice (2001), Varieties of Capitalism: the Institutional Foundations of Comparative Advantage (Oxford and New York, Oxford University Press).

Heery, E. (1998), 'The Relaunch of the Trades Union Congress,' British Journal of Industrial Relations, 36, 3, 339-360.

Heery, E., R. Delbridge, M. Simms, J. Salmon, D. Simpson and P. Stewart (1998), ' "It's Not a Recruitment Drive, It's the Rest of Your Life": New Union Organising in the United Kingdom.' Paper presented at the UCLEA/AFL-CIO Education Conference on 'Organizing for Keeps: Building a 21st Century Labor Movement,' Lebaron Wyndham Hotel, San Jose, California, April 30-May 2.

Heery, E., J. Kelly and J. Waddington (2001), 'Union Revitalization in Britain,' Paper presented at the International Seminar on Labour Movement Revitalization, International Labour Organisation, Geneva, April 19-21. 
Hethy, L. (1994), 'Tripartism in Eastern Europe,' in R. Hyman and A. Ferner (eds), New Frontiers in European Industrial Relations (Oxford Cambridge, Blackwell), pp. 312-336.

lankova, E. A. (1998), 'The Transformative Corporatism of Eastern Europe,' Eastern European Politics and Societies, 12, 2, 222-264.

lankova, E. A. (2000), 'Multi-Level Bargaining During Bulgaria's Return to Capitalism,' Industrial and Labor Relations Review, 54, 1, 115-137.

lankova, E. A. (2002), Eastern European Capitalism in the Making (Cambridge and New York, Cambridge University Press).

Kabaj, M. (1998), 'Searching for a New Results-Oriented Wage Negotiation System in Poland,' in Daniel Vaughan-Whitehead (ed.) Paying the Price: The Wage Crisis in Central and Eastern Europe (New York, St. Martin's Press), pp. 234-271.

Linz, J. J. and A. Stepan (1996), Problems of Democratic Transition and Consolidation: Southern Europe, South America, and Post-Communist Europe (Baltimore and London, The Johns Hopkins University Press).

Locke, R. and L. Baccaro (1999), 'The Resurgence of the Italian Unions?' In A. Martin and G. Ross (eds), The Brave New World of European Labor (New York, Berghahn Books), pp. 217-268.

Lubinski, M., (ed.) (1998), Poland International Economic Report, 1997-1998 (Warsaw, Warsaw School of Economics).

Martin, R., A. Vidinova and S. Hill (1996), 'Industrial Relations in Transition Economies: Emergent Industrial Relations Institutions in Bulgaria.' British Journal of Industrial Relations, 34, 1, 3-24.

Millard, F. (1999), Polish Politics and Society (London and New York, Routledge).

Millard, F. (1994), 'The Shaping of the Polish Party System, 1989-93,' East European Politics and Societies, 8, 3, 467-494.

Ogrodzinski, P. (1996), 'The Four Faces of Civil Society' (Warsaw, 1991, unpublished manuscript), cited in J. J. Linz and A. Stepan, Problems of Democratic Transition and consolidation: Southern Europe, South America, and Post-Communist Europe (Baltimore and London, The Johns Hopkins University Press), p. 271.

Petkov, K. and G. Gradev (1995), 'Bulgaria,' in J. Thirkell, R. Scase and S. Vickerstaff (eds) Labour Relations and Political Change in Eastern Europe (London, UCL Press).

Sally, R. and D. Webber (1994), 'The German Solidarity Pact: A Case Study in the Politics of the Unified Germany' (manuscript).

Schmitter, P. and G. Lehmbruch (eds) (1979), Trends Toward Corporatist Intermediation (Beverly Hills, Sage).

Sewerynski, M. (1995), 'Evolution of Polish Labour Law and Collective Labour Relations During the Period of Post-Communist Transformation,' in M. Sewerynski (ed.) Polish Labour Law and Collective Labour Relations in the Period of Transformation (Warsaw, Ministry of Labour and Social Policy), pp. 21-50. 
Springer, B. (1992), The Social Dimension of 1992: Europe Faces a New EC (New York, Praeger).

'The Labour Market in Poland,' OECD, Centre for Cooperation with Economies in Transition.

Streeck, W. (1991), 'More Uncertainties: German Unions Facing 1992,' Industrial Relations 30, 3, 317347.

Thelen, K. (2000), 'Why German Employers Cannot Bring Themselves to Dismantle the German Model,' in T. Iversen, J. Pontusson and D. Soskice (eds) Unions, Employers and Central Banks (New York, Cambridge University Press), pp. 138-169.

Thelen, K. (2001), 'Varieties of Labor Politics in the Developed Democracies,' in P. Hall and D. Soskice (eds), Varieties of Capitalism: The Institutional Foundations of Comparative Advantage (Oxford and New York, Oxford University Press), pp. 71-103.

Thelen, K. and I. Kume (1999), 'The Effects of Globalization on Labor Revisited: Lessons from Germany and Japan,' Politics and Society, 27, 4, 477-505.

Thirkell, J. E. M. and E. A. Tseneva (1992), 'Bulgarian Labour Relations In Transition: Tripartism and Collective Bargaining,' International Labour Review, 131, 3, 355-366.

Tsoukalis, L. (1997), The New European Economy Revisited (Oxford, Oxford University Press).

Turner, L. (1996), 'The Europeanisation of Labour: Structure before Action,' European Journal of Industrial Relations, 2, 3, 325-344.

Turner, L. (1998), Fighting for Partnership: Labor and Politics in Unified Germany (Ithaca, Cornell University Press).

Visser, J. (1999), 'The Revival of Social Dialogue in Europe,' Perspectives on Work, 3, 1, 4-7.

Wade, L. L. A. J. Groth and P. Lavelle (1994), 'Estimating Participation and Party Voting in Poland: The 1991 Parliamentary Elections', East European Politics and Societies, 8, 1, 94-121.

Wilensky, H. L. (2002), Rich Democracies: Political Economy, Public Policy, and Performance (Berkeley, University of California Press). 